\title{
Chinese Internet Business and Human Rights
}

\author{
Min JIANG*
}

Keywords: China, Google, human rights, internet business, social media

\section{INTRODUCTION}

The dubious human rights record of foreign internet companies in China has been the subject of popular and scholarly scrutiny. ${ }^{1}$ This article surveys three recent developments in the intersection of information technology and human rights in China: (i) the rise and fall of Chinese social media firms (Sina Weibo and WeChat) and the prospect for advancing human rights via Chinese tech companies; (ii) the social impacts of foreign internet firms currently operating in China; and (iii) Chinese internet businesses' 'going out' strategy and its human rights ramifications abroad.

A number of tectonic shifts have profoundly shaped the context for evaluating the impact of Chinese internet businesses on human rights: the tumultuous Arab Spring that challenges the legitimacy of authoritarian governance in what is dubbed 'democracy's fourth wave'; ${ }^{2}$ the Snowden Affair that exposed the US government's mass surveillance programs and the hypocrisy of its public rhetoric of rule of law and democracy; the promotion and bankruptcy of Washington's internet freedom agenda; and the relative decline of the US as a global power along with China's rise.

While the term 'human rights' invokes a rich tapestry of meanings, the primary concern of this essay is the right to speech on the Chinese internet. It is well known that the Chinese government adopts sophisticated tactics to control the political consequences of the Web. ${ }^{3}$ Recently the ruling Communist Party (the Party) has openly warned officials not to speak about universal values, free press, civil society, civil rights, the bureaucratic capitalist class, and the Party's errors in history or judicial

* $\mathrm{PhD}$; Associate Professor of Communication Studies, UNC Charlotte; Research Affiliate at the Center for Global Communication Studies, University of Pennsylvania.

1 See, e.g., Min Jiang, 'Internet Companies in China: Dancing between the Party Line and the Bottom Line' (2012) 47 Asie Visions, http://www.ifri.org/en/publications/enotes/asie-visions/internet-companies-china-dancing-betweenparty-line-and-bottom-line (accessed 26 August 2015). Michael Santoro, China 2020: How Western Businesses Canand Should - Influence Social and Political Change in the Coming Decade (Ithaca, NY: Cornell University Press, 2009).

2 Philip Howard and Muzammil Hussain, Democracy's Fourth Wave (Oxford, UK: Oxford University Press, 2013).

3 See Santoro, note 1. 
independence. ${ }^{4}$ Of course, this is not to say that China has not made tremendous progress in human rights development. In fact, the PRC's spectacular economic growth in the past four decades, which has lifted more than 500 million people out of poverty, ${ }^{5}$ is without doubt a remarkable achievement of economic and social human rights. However, progress in the political realm has lagged far behind and rising inequality and rampant corruption are threatening the very social stability the party-state claims to preserve.

\section{Limited Right to Speech on Chinese Social Media}

Former President Bill Clinton once compared the Chinese government's effort to control the internet to 'trying to nail Jell-O to a wall'. However, with the coerced consent of Chinese internet firms, the Party seems to have done the impossible: growing the internet in China without triggering regime collapse. Even widely-adopted Chinese social media platforms such as Sina Weibo and Tencent's WeChat have not fundamentally altered the situation.

Fanfou, China's first microblog site, was created in May 2007 but was shut down in July 2009 after the Xinjiang ethnic riots. In August 2009, Sina Weibo started to offer a censored version. It grew to 300 million users in two years and listed on NASDAQ in 2014. Sina Weibo, at its height, was teeming with 'Weibo celebrities' as well as anyone with anything interesting or provocative to share, making it the epicentre of China's public opinion. Its top ten celebrities, including former Google China CEO Kaifu Lee, have over 50 million fans, a number that rivals the Communist Party's 85 million membership.

Sina Weibo's popularity makes it an explosive site for exposing official scandals and indiscretions. A week after the Wenzhou high-speed train collision in 2011, first reported on Sina Weibo by users, more than 10 million comments were posted about the crash. Public furor over the rescue efforts and attempts to bury the truth helped bring down the Minister of Railway. Sina Weibo's popularity, however, comes at a hefty censorship cost. Sina reportedly hired over 1,000 people to manually monitor and delete posts around the clock in addition to auto-filtering. ${ }^{6}$

Shaken by the Arab Spring, Chinese authorities pulled out all stops to rein in public dissent on social media: real name registration asked users to register their real identities with Chinese microblogging services linked to their national ID cards, mobile phones, or other identifications; reporters were barred from releasing information on social media without permission; outspoken Weibo celebrities were nudged to 'behave'; and state 'anti-rumour' campaigns carried stiff penalties for posting 'rumors'. Official mouthpiece People's Daily's online outlet People's Net (2015) even openly warned Sina that it would face suspension if failing to manage 'public complaints'.

\footnotetext{
4 Chris Buckley, 'China Warns Officials against “Dangerous” Western Values', New York Times (13 May 2013), http://is.gd/kjyRET (accessed 2 August 2015).

5 World Bank, China Overview (2015), http://is.gd/aLOQlQ (accessed 2 August 2015).

6 King-wa Fu, Chung-hong Chan, and Michael Chau, 'Assessing Censorship on Microblogs in China: Discriminatory Keyword Analysis and Impact Evaluation of the "Real Name Registration” Policy', (2013) 17(3) IEEE Internet Computing 42.
} 
Such tactics have seriously limited Chinese netizens' right to speech. Moreover, they have turned private firms into part of the Party's censorship apparatus. Through licensing rules that require Internet Content Providers (ICPs) to obtain a license that is then displayed online, reviewed, and renewed, ${ }^{7}$ the Chinese government effectively subjects servers and the data that passes through these servers to its jurisdiction and censorship. Although domestic internet companies are coerced to comply, they have also benefited from various forms of government protection and incentives intended to turn these firms into "national champions" and global powerhouses. ${ }^{8}$

Another big challenge to Sina Weibo and its popularity stems from user migration to WeChat, a small-group messaging app. While Weibo posts are mostly public and can be commented upon by anyone, the group size on WeChat is usually capped at 100, thus turning Weibo's 'town-square' chatter into semi-private conversations and limiting the rapid spread of public controversies. Authorities have also cracked down on WeChat, asking it to remove politically 'harmful' posts and accounts. So far, Chinese social media firms are unlikely to pose serious challenges to the political status quo.

\section{Foreign Internet Firms' Faustian Bargain in China}

Foreign internet firms have adopted a range of approaches to doing business in China with varied ethical implications. Google's approach has swung between detachment and resistance. After its 2010 decision to leave China, the search giant closed most of its services in mainland China including Google Images and Google Music. Google Maps still operates inside China but is barred from offering Street View. Google Translate is the only other service available to mainland users. Since 2010, mainland queries to Google.cn have been auto-directed to Google.com.hk, subject to filtering by the Great Firewall. However, at the end of 2014, both Google Search and Gmail were blocked inside mainland China indefinitely.

Google has been pushing back. In April 2015, Google and Mozilla, citing trust and security beaches caused by MCS Holdings, an intermediate certificate authority under CNNIC (China's official web registrar), announced Google's Chrome and Mozilla's Firebox would no longer recognize certificates issued by CINNIC. If CNNIC do not reapply for trusted status, after 'a limited time', many mainland users might be unable to access .cn e-commerce sites. Chrome is a dominant web browser in China with a 52 per cent market share, compared to Internet Explorer's 23 per cent in 2014. ${ }^{9}$

In hindsight, Google's foray into China and its Faustian bargain with Beijing serve as a reminder of the risks involved in conducting business in countries with restricted access to information and ideas. However, Google is not the only one to face the challenges of what George Brenkert has called 'obedient complicity'. ${ }^{10}$ Unlike Google, Apple and Microsoft refused to block the certificates issued by CNNIC and took a

7 Min Jiang, 'Authoritarian Informationalism: China's Approach to Internet Sovereignty', (2010) 30(2) SAIS Review of International Affairs 71.

8 See Min Jiang, note 1.

9 Dan Goodin, 'Google Chrome will Banish Chinese Certificate Authority for Breach of Trust [updated]' Ars Technica (1 April 2015), http://is.gd/cuteNG (accessed 2 August 2015).

10 George Brenkert, 'Google, Human Rights, and Moral Compromise' (2008) 84(4) Journal of Business Ethics 453. 
middle ground. Apple continues to list CNNIC, but not MCS, as a trusted source, while Microsoft had a security update, discredited MCS certificates, and took no action against CNNIC. ${ }^{11}$ Their responses reflect a deeply ambivalent approach to doing business in China, a market critical to their bottom line. China is not only the assembly line for many of Apple's products but has also become the biggest market for Apple devices. ${ }^{12}$ Microsoft has over 20 years of investment in China. Yet, in 2014, Beijing opened an anti-trust case against Microsoft and stopped purchasing its software. Following the Snowden revelations, China has taken steps to 'purge most foreign technology from banks, the military, state-owned enterprises and key government agencies by 2020 ' ${ }^{13}$ possibly stoked by fear of security breaches brought by potential secretive dealings between the US government and US tech firms. This purge may also limit foreign firms' influence in China and encourage domestic companies to become more competitive.

Given their business ties in China, many leading Western internet companies are likely to comply with Beijing's demands. Apple has benefited from weak regulatory oversight over supplier Foxconn's labour abuses that resulted, among other things, in multiple suicides. ${ }^{14}$ In 2013 Apple removed an app allowing Chinese users to access banned books, as well as Open Door, an app enabling users to bypass the Great Firewall, and the FreeWeibo app for bypassing filtering on Sina Weibo. ${ }^{15}$ In 2015, Apple was the first Western tech firm to accept China's security checks.

Facebook's Mark Zuckerberg, eagerly eying the Chinese market, had a copy of Chinese President Xi's book at his desk during Chinese Web czar's Silicon Valley visit. ${ }^{16}$ In 2015 , Facebook suspended exile writer Liao Yiwu's account. ${ }^{17}$ While Google may be bucking the trend given its tiny search market share and assets in China, droves of other leading Western Internet businesses including LinkedIn, Amazon, Apple, Microsoft, and Facebook seem more eager to please and comply with Chinese authorities. ${ }^{18}$

\section{The Human Rights Implications of Chinese Internet Companies 'Going Out'}

The expansion of Chinese internet companies overseas is also resulting in mixed human rights impacts. As China rivals the US to become the world's largest economy with

\footnotetext{
11 Joel Hruska, 'Apple, Microsoft Buck Trend, Refuse to Block Unauthorized Chinese Root Certificates', ExtremeTech (9 April 2015), http://is.gd/hhEAsy (accessed 2 August 2015).

12 Kevin Bostic, 'China Surpasses US as Biggest Market for Apple, Android Devices', Apple Insider (18 February 2013), http://is.gd/Qa9rI0 (accessed 2 August 2015).

13 Dina Bass, 'Microsoft Shares Plummet after Sales Hit in China, Japan', Bloomberg Business (26 January 2015), http://is.gd/AYfJ01 (accessed 2 August 2015).

14 Jack Qiu, Melissa Gregg, and Kate Crawford, 'Circuits of Labor: A Labour Theory of the iPhone Era', (2014) 12(2) Triple C: Communication, Capitalism \& Critique.

15 Shane Cole, 'Apple Pulls Another Anti-Censorship App from China's iOS Apple Store', Apple Insider (13 December 2013), http://is.gd/X9hhkp (accessed 2 August 2015).

16 Paul Mozur, 'Warm West Coast Reception for China's Web Czar (Chillier in Washington)', New York Times (8 December 2014), http://is.gd/SLRLKr (accessed 2 August 2015).

17 Chris Matthews, 'China Praises Facebook's Decision to Censor Dissident', Fortune (13 January 2015), http://is.gd/ ArNgg0 (accessed 2 August 2015).

18 Josh Horowitz, 'A New Wave of US Internet Companies is Succeeding in China-By Giving the Government What It Wants’, Quartz (26 June 2015), http://is.gd/StW7Gd (accessed 2 August 2015); Mozur, note 15.
} 
increasing trade relations worldwide, its internet industry has been casting its sights abroad, reversing previous patterns where China was on the receiving end of the information technology trade.

In 2014 alone, Alibaba, Baidu, and Tencent — the Chinese Internet's 'big three' - have spent an estimated $\$ 15$ billion investing in or acquiring other firms, including many overseas. Among them, Alibaba took the spotlight as it debuted in 2014 on the New York Stock Exchange, raising its market value to $\$ 250$ billion overnight. Since then, it has been on a spending spree, investing in Kabam (online gaming), Lyft (a mobile car-sharing app), Tango (mobile video chat) in the US; Paytm (mobile payments) in India; a cloud computing base in Dubai; and many more. While the human rights impacts of Alibaba's business may not be immediately clear, its chairman Jack Ma's previous remarks may be quite revealing: 'I'm not a political group; I am a businessman'. ${ }^{19}$ Recently, Ma's defence of the Chinese government's crackdown on protesters in Tiananmen Square drew criticism from Netcitizens. Ma was CEO of Alibab in 2005 (then 39 per cent owned by Yahoo) when it turned over user data to Chinese authorities resulting in the imprisonment of journalist Shi Tao. ${ }^{20}$

Tencent's WeChat, China's homegrown instant messaging app, now has over 100 million users abroad. The company regularly monitors and removes 'sensitive' accounts and messages inside China, and such practices reportedly also have been extended to users overseas. ${ }^{21} \mathrm{WeChat}$ claimed such incidents as a 'passing glitch' but their occurrences raise questions about WeChat and other Chinese Internet firms' surveillance, privacy, and censorship capabilities as they expand beyond Chinese borders. ${ }^{22}$

The NSA scandal not only discredited the US government and tech companies, but also makes it harder for the likes of WeChat to convince users, especially those overseas, of the absence of corporate or state data surveillance as data passes through their servers inside China. Freitas (2014) argues that concerns for foreign users of Chinese internet and mobile services are three-fold: (i) censorship of targeted keywords beyond Chinese borders; (ii) state data surveillance that can be used against users in the future; and (iii) wholesale extraction of data and insertion of malware into user devices. These potential risks highlight the importance of these Chinese companies' legal obligations to and protections for their users outside China. ${ }^{23}$

Some of these concerns are already playing out in Brazil, a market Baidu hopes to develop besides Egypt, Thailand, and Indonesia. A Brazilian court recently ruled that Baidu's antivirus app, DU Speed Booster, used anti-competitive tactics resulting in over 700,000 uninstalls of PSafe, a leading Brazilian mobile security app (backed by Baidu Chinese rival Qihoo360), by labeling it as a virus and coercing users to uninstall it. While DU Speed Booster is no longer available in Google Play's Brazil store, the case exposed

19 Quoted in Paul Mozur and Josh Chin, 'Alibaba Founder Jack Ma’s Reported Tiananmen Comments Draw Ire', Wall Street Journal (18 July 2013), http://is.gd/gUOALb (accessed 2 August 2015).

20 Ibid.

21 BBC, 2013 BBC, ‘China's Tencent Denies WeChat App Global Censorship', BBC (14 January 2013), http://is.gd/ A5kB06 (accessed 2 August 2015).

22 Nathan Freitas, 'People around the World are Voluntarily Submitting to China's Great Firewall. Why?' Slate (5 January 2015), http://is.gd/0vyLv0 (accessed 2 August 2015).

23 Ibid. 
Baidu's problematic terms of service that are non-compliant with Marco Civil, the Brazilian Internet 'bill of rights' passed in 2014, requiring user consent and disclosure of data collection and use. ${ }^{24}$

As the likes of Alibaba, WeChat, and Baidu expand globally, we are on the cusp of encountering more complex ramifications of the Chinese internet's 'going out'. While these companies bring with them investments, technology, and know-how, they also pose new challenges for user data and rights globally.

\section{Conclusion}

The right to speech is a fundamental component of the various human rights conventions spanning social, cultural, economic, and political realms. As domestic and foreign internet firms 'exert growing influence over the political and civil lives of people all over the world', ${ }^{25}$ they carry a growing responsibility to respect and preserve human rights. Although human rights in China have traditionally focused on collective socioeconomic justice, the right to speech is increasingly a means to achieve the very socioeconomic justice that the Chinese state promises to deliver to its population. Perhaps former Premier Wen Jiabao knew this the best as he frankly stated in his 2010 CNN interview: 'The people's wishes for, and needs for, democracy and freedom are irresistible'. ${ }^{26}$

\footnotetext{
24 Julie Ruvolo, 'Brazilian Becomes a New Front in the Battle between Baidu and Qihoo', TechCrunch (1 March 2015), http://is.gd/cKq6QD

25 Rebecca MacKinnon, Ranking Digital Rights (2015), https://rankingdigitalrights.org/ (accessed 2 August 2015).

26 Tania Branigan, 'Wen Jiabao Talks of Democracy and Freedom in CNN Interview', The Guardian (18 February 2013), http://is.gd/titUAd (accessed 2 August 2015).
} 